\title{
PReS-FINAL-2158: Effect of canakinumab on functional ability and health-related quality of life in systemic juvenile idiopathic arthritis (SJIA) patients
}

\author{
P Quartier ${ }^{1 *}$, N Ruperto ${ }^{2}, N$ Wulffraat ${ }^{2}, H$ Brunner ${ }^{3}$, R Brik ${ }^{2}, L$ Mccann ${ }^{2}$, H Foster $^{2}$, M Frosch ${ }^{2}, V$ Gerloni ${ }^{2}$, L Harel $^{2}$,

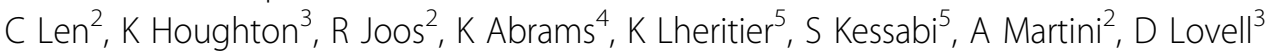

From 20th Pediatric Rheumatology European Society (PReS) Congress

Ljubljana, Slovenia. 25-29 September 2013

\section{Introduction}

Canakinumab (CAN), a selective, fully human, antiinterleukin- $1 \beta$ monoclonal antibody, has been shown to be efficacious in SJIA patients (pts) in 2 phase 3 trials: Trial 1 (4-wk, randomized placebo [PBO]-controlled) and Trial 2 (open-label CAN treatment [Part 1] followed by a randomized $\mathrm{PBO}$-controlled withdrawal phase [Part 2]). In Trial 1 , statistically significantly more CAN than $\mathrm{PBO}$ group pts achieved an adapted pediatric ACR 30 response and in Trial 2, CAN allowed successful reduction/ discontinuation of steroids and significantly reduced risk of flare. Safety profile of CAN was in line with expectations for a biologic agent in active SJIA. The persistent disabling features of SJIA and chronic pain can have a negative impact on health-related quality of life (hrqol). These outcomes were evaluated in the CAN phase 3 program.

\section{Objectives}

To report pt-reported functional ability and hrqol outcomes from the CAN phase 3 program.

\section{Methods}

The phase 3 analysis included 84 pts (CAN, 43; PBO, 41) in Trial 1 and 177 pts in Trial 2 (71 from Trial 1 entered) in Part 1, and 100 rolled into Part 2 (CAN, 50; $\mathrm{PBO}, 50)$. Pt-reported assessments included functional ability (as measured by the Childhood Health Assessment Questionnaire $\left[\mathrm{CHAQ}^{\odot}\right]$ ), pain (measured on a visual analog scale [VAS] of 0-100 $\mathrm{mm}$ as part of the $\mathrm{CHAQ}^{\odot}$ ), and physical (phs) and psychosocial (pss) health status in 5-18 year old pts., according to the Child Health Questionnaire-Parent Form (CHQ-PF50).

\section{Results}

In Trial 1, CAN treatment was associated with a significant improvement in CHAQ disability score (estimated difference [ED] of -0.69 over time vs PBO in the least square mean $[\mathrm{LSM}]$ change from baseline $[\mathrm{BL}][\mathrm{p}=0.0002]$ ), which was $\sim 3.6 \times$ the minimal clinically important difference of -0.19 . The LSM in overall pain intensity were significantly lower (both $\mathrm{p}<0.0001$ ) in the CAN group vs

Table 1 Patient- or Parent-reported functional ability and hrqol parameters in Trial 2

\begin{tabular}{lcccc}
\hline Outcome measure, mean (SD) & $\begin{array}{c}\text { Baseline } \\
\text { CAN, N = 177 }\end{array}$ & $\begin{array}{c}\text { End of Part 1 } \\
\text { CAN, N = 177 }\end{array}$ & $\begin{array}{c}\text { End of Part 2 } \\
\text { CAN, N = 50 }\end{array}$ & $\begin{array}{c}\text { End of Part 2 } \\
\text { PBO, N = 50 }\end{array}$ \\
\hline CHAQ disability score & $1.7(0.8)$ & $0.74(0.9)$ & $0.5(0.9)$ & $0.6(0.8)$ \\
Pain (VAS, 0-100 mm) & $66.6(23.3)$ & $20.2(25.8)$ & $13.6(26.9)$ & $17.0(24.2)$ \\
CHQ-PF50 phs score & $16.1(14.3)$ & $37.7(17.2)$ & $43.6(17.4)$ & $39.0(18.1)$ \\
CHQ-PF50 pss score & $41.6(11.1)$ & $50.7(11.1)$ & $53.6(11.3)$ & $52.7(9.8)$ \\
\hline
\end{tabular}

Results are based on patients with both baseline and post-baseline values. N18 years old

${ }^{1}$ Necker-Enfant Malades Hospital, Paris, France

Full list of author information is available at the end of the article 
PBO both at Day 15 (ED, -46.42) and Day 29 (ED, -41.86). CHQ-PF50 phs and pss scores also showed significant improvements over time (ED CAN vs PBO in LSM change from $\mathrm{BL}, 12.07$ and 7.28; $\mathrm{p}<0.005$ for both). Improvements in CHAQ disability, CHQ-PF50 phs and pss, and VAS pain scores were also observed in Trial 2 (Table 1).

\section{Conclusion}

Treatment with CAN demonstrated rapid, marked and continued improvement in patient-reported functional ability and hrqol of SJIA patients.

\section{Disclosure of interest}

P. Quartier Grant/Research Support from: Abbvie, ChugaiRoche, Novartis, Pfizer, Consultant for: Abbvie, BMS, Chugai-Roche, Novartis, Pfizer, Servier, Sweedish Orphan Biovitrum, Speakers Bureau: Chugai-Roche, Novartis, Pfizer, N. Ruperto Grant/Research Support from: To Gaslini Hospital: Abbott, Astrazeneca, BMS, Centocor Research \& Development, Eli Lilly and Company, "Francesco Angelini", Glaxo Smith \& Kline, Italfarmaco, Novartis, Pfizer Inc., Roche, Sanofi Aventis, Schwarz Biosciences gmbh, Xoma, Wyeth Pharmaceuticals Inc., Speakers Bureau: Astrazeneca, Bristol Myers and Squibb, Janssen Biologics B.V., Roche, Wyeth/Pfizer, N. Wulffraat Consultant for: Novartis, Pfizer, Roche, H. Brunner Consultant for: Novartis, Genentech, Medimmune, EMD Serono, AMS, Pfizer, UCB, Jannsen, Speakers Bureau: Genentech, R. Brik Grant/Research Support from: Novartis, Consultant for: Novartis, L. Mccann: None declared., H. Foster Grant/Research Support from: Pfizer, biomarin, Speakers Bureau: Pfizer, M. Frosch: None declared., V. Gerloni: None declared., L. Harel: None declared., C. Len: None declared., K. Houghton: None declared., R. Joos: None declared., K. Abrams Shareholder of: Novartis, Employee of: Novartis, K. Lheritier Shareholder of: Novartis, Employee of: Novartis, S. Kessabi Employee of: Novartis, A. Martini Grant/Research Support from: Abbott, Astrazeneca, Bristol Myers and Squibb, Janssen Biologics B.V., Ely Lilly and Company, "Francesco Angelini", Glaxo Smith \& Kline, Italfarmaco, Novartis, Pfizer Inc., Roche, Sanofi Aventis, Schwarz Bisciences, gmbh, Xoma, Wyeth Pharmaceuticals Inc.(Consulting fee). The GASLINI hospital which is a public hospital where I work as full time employee has received contributions to support the research activities of the network of PRINTO (http://www. printo.it), Consultant for: Abbott, Astrazeneca, Bristol Myers and Squibb, Janssen Biologics B.V., Ely Lilly and Company, Francesco A, Glaxo Smith \& Klime, Italfarmaco, Novartis, Pfizer Inc., Roche, Sanofi Aventis, Schwarz Biosciences gmbh, Xoma, Wyeth Pharmaceuticals, Speakers Bureau: Astellas, Astrazeneca, Bristol Myers and Squibb, Glaxo Smith \& Kline, Italfarmaco, medimmune, Novartis, D. Lovell Grant/Research Support from: NIH,
Consultant for: Astra-Zeneca, Centocor, Jannsen, Wyeth, Amgen, Bristol-Meyers Squibb, Abbott, Pfizer, Regeneron, Hoffman La-Roche, Novartis, Genentech, Speakers Bureau: Genentech, Roche.

\section{Authors' details}

${ }^{1}$ Necker-Enfant Malades Hospital, Paris, France. ${ }^{2}$ PRINTO-Istituto Gaslini, Genova, Italy. ${ }^{3}$ PRCSG, Cincinnati, OH, USA. ${ }^{4}$ Novartis Pharmaceuticals

Corporation, EH, NJ, USA. ${ }^{5}$ Novartis Pharma AG, Basel, Switzerland.

Published: 5 December 2013

doi:10.1186/1546-0096-11-S2-P170

Cite this article as: Quartier et al:: PReS-FINAL-2158: Effect of

canakinumab on functional ability and health-related quality of life in systemic juvenile idiopathic arthritis (SJIA) patients. Pediatric

Rheumatology 2013 11(Suppl 2):P170.

\section{Submit your next manuscript to BioMed Central} and take full advantage of:

- Convenient online submission

- Thorough peer review

- No space constraints or color figure charges

- Immediate publication on acceptance

- Inclusion in PubMed, CAS, Scopus and Google Scholar

- Research which is freely available for redistribution

Submit your manuscript at www.biomedcentral.com/submit 